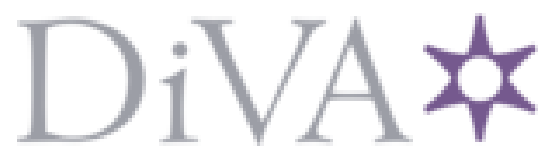

http://www.diva-portal.org

This is the published version of a paper published in German Law Journal.

Citation for the original published paper (version of record):

Derlén, M., Lindholm, J. (2015)

Characteristics of Precedent: The Case Law of the European Court of Justice in Three

Dimensions.

German Law Journal, 16(5): 1073-1098

Access to the published version may require subscription.

N.B. When citing this work, cite the original published paper.

Permanent link to this version:

http://urn.kb.se/resolve?urn=urn:nbn:se:umu:diva-1 10469 


\title{
Articles
}

\section{Characteristics of Precedent: The Case Law of the European Court of Justice in Three Dimensions}

\author{
By Mattias Derlén ${ }^{*}$ \& Johan Lindholm ${ }^{* *}$
}

\begin{abstract}
The case law of the Court of Justice of the European Union (CJEU) is one of the most important sources of European Union law. However, case law's role in EU law is not uniform. By empirically studying how the Court uses its own case law as a source of law, we explore the correlation between, on the one hand, the characteristics of a CJEU casetype of action, actors involved, and area of law-and, on the other hand, the judgment's "embeddedness" in previous case law and value as a precedent in subsequent cases. Using this approach, we test, confirm, and debunk existing scholarship concerning the role of CJEU case law as a source of EU law. We offer the following conclusions: that CJEU case law cannot be treated as a single entity; that only a limited number of factors reliably affect a judgment's persuasive or precedential power; that the Court's use of its own case law as a source of law is particularly limited in successful infringement proceedings; that case law is particularly important in preliminary references-especially those concerning fundamental freedoms and competition law; and that initiating Member State and the number of observations affects the behavior of the Court.
\end{abstract}

\footnotetext{
*Umeå University, Department of Law, mattias.derlen@umu.se.

** Umeå University, Department of Law, johan.lindholm@umu.se. This research was made possible by the generous support of the Swedish Research Council. The authors would also like to thank Andreas Nordström for his help in collecting the data and Staffan Ingmanson, Jan Leidö, Elizabeth Perry, and Martin Rosvall for their helpful comments.
} 


\section{A. Introduction}

From its inception, the European Union (EU) has included a court entrusted with ensuring that the law is respected in the interpretation and application of Treaties and legislative acts. ${ }^{1}$ It was initially clear that the Court of Justice of the European Union (CJEU) was to play an important role in settling disputes, but few anticipated how instrumental the Court would become in the development of EU law. ${ }^{2}$

Few would dispute that the judgments of the CJEU constitute an important source of European Union law. When it renders a judgment, the CJEU settles the case at hand and also sets a precedent. ${ }^{3}$ Collectively, these precedents constitute case law, sometimes even "settled" or "established" case law, which can serve as a legal basis for settling subsequent cases, sometimes extensively or even exclusively. ${ }^{4}$ For example, this is the case with the principle of state liability, for which the Court openly refers to its past judgment Francovich as the source of law. ${ }^{5}$

While it is clear that case law-law established through judgments-constitutes one of the primary sources of European Union law, a lot of questions remain regarding CJEU case law. This study explores when-that is, under what circumstances-CJEU case law is an important source of law. ${ }^{6}$ As explained more fully below, this is achieved by answering two, at least partially distinguishable, questions: (i) When does the Court cite case lawpersuasive power-and, (ii) which judgments become strong precedents-precedential power?

\footnotetext{
${ }^{1}$ Treaty Establishing the European Coal and Steel Community, art. 31, Apr. 18, 1951 ("La Cour assure le respect du droit dans l'interprétation et l'application du présent Traité et des règlements d'exécution.") (now TEU art. 19).

${ }^{2}$ See, e.g., Karen J. Alter, Who are the 'Masters of the Treaty'?: European Governments and the European Court of Justice, 52 INT'L ORG. 121 (1998); J.H.H. Weiler, The Transformation of Europe, 100 YALE L.J. 2403 (1991); PAUL CRAIG \& GRÁINNE DE BÚRCA, EU LAW 63-66 (2011).

3 John J. Barceló, Precedent in European Community Law, in INTERPRETING PRECEDENT 407, 417 (D. Neil McCormick et al. eds., 1997). Barceló notes that the Court never explicitly refers to its previous judgments as "precedents". Id. However, the Court has acknowledged that the General Court's judgments can "constitute a precedent for future cases." Case C-197/09 RX-II, M v. EMEA, 2009 E.C.R. 662, para. 62; Case C-334/12 RX-II, Jaramillo et al. v. EIB, 2013 E.C.R. 134, para. 50.

${ }^{4}$ See, e.g., Case C-409/06, Winner Wetten GmbH v. Bürgermeisterin der Stadt Bergheim, 2010 E.C.R. I-8015, paras. $36,39,53,58$. On the importance of settled case law in proceedings before the CJEU, see MITCHEL LASSER, Judicial Deliberations-A ComparatiVe ANALYSIS OF JUdicial TRANSPARENCY AND LEGITIMACY 107-12 (2004).

${ }^{5}$ See, e.g., Case C-176/12, Association de médiation sociale v. Union locale des syndicats CGT et al., para. 50 (“[A] party injured as a result of domestic law not being in conformity with European Union law can nonetheless rely on the judgment in Joined Cases C-6/90 and C-9/90 Francovich and Others [1991] ECR I-5357.").

${ }^{6}$ In a forthcoming article, Mattias Derlén \& Johan Lindholm, Peek-a-boo, It's a Case Law System (forthcoming 2015), we explore the question of how CJEU case law is an important source of law.
} 
This study seeks to contribute to existing European legal scholarship by empirically testing commentators' claims about the role of CJEU case law as a source of EU law. ${ }^{7}$ By focusing on the role of case law as a source of law in practice and under particular circumstances, we circumvent the sometimes-paralyzing, system-wide discussion about the nature of precedent in CJEU law on a scale between binding and persuasive. ${ }^{8}$ We find that the CJEU and its case law cannot be reduced to a single role. While it is commonplace to compare the CJEU to constitutional courts, ${ }^{9}$ we empirically demonstrate in which situations the Court establishes, and uses, case law. This paper provides insight into the Court and into its case law equally, by defining the situations where the Court functions as a constitutional referee, as an infringement confirmer, and everything in between.

\section{B. Case Law from a Network Perspective}

\section{Introduction: Tomorrow's Yesterday}

The common, and deceptively simple, practice of a court citing a previous judgment contains a surprising amount of information. First, it must be noted that a citation affects both the cited judgment and the citing judgment. ${ }^{10}$ As elegantly explained by Schauer: ${ }^{11}$

An argument from precedent seems at first to look backward. The traditional perspective on precedent, both inside and outside of law, has therefore focused on the use of yesterday's precedents in today's decisions. But in an equally if not more important way, an argument from precedent looks forward as well, asking us to view today's decision as a precedent for

\footnotetext{
${ }^{7}$ These claims are presented in the beginning of Sections C-E. See infra Sections C-E. While the study's main contribution is to legal science, we draw knowledge and experience from a wide range of sciences when it comes to methodology. We realize that many legal readers may be more interested in the findings than the method, but we feel that full methodological disclosure is necessary.

${ }^{8}$ See Barceló, supra note 3, at 415-16 (providing an overview of existing scholarship on this topic); see also A.G. Toth, The Authority of Judgments of the European Court of Justice: Binding Force and Legal Effects, 4 Y.B. EUR. L. 1 (1984).

${ }^{9}$ See, e.g., Alec Stone Sweet, The European Court of Justice, in THE EVolution OF EU LAW 121 (Paul Craig \& Gráinne de Búrca eds., 2011); Martin Shapiro, The European Court of Justice, in THE Evolution OF EU LAW 321 (Paul Craig \& Gráinne de Búrca eds., 1999); Bo Vesterdorf, A Constitutional Court for the EU?, 4 INT'L J. ConstiTUTIONAL L. 607 (2006).

${ }^{10}$ See also infra Figure 1.

${ }^{11}$ Frederick Schauer, Precedent, 39 STAN. L. REV. 571, 572-73 (1987).
} 
tomorrow's decisionmakers. Today is not only yesterday's tomorrow; it is also tomorrow's yesterday.

Thus, two different types of information can be extracted from a single citation: The outward citation from the citing judgment that reveals information about when precedents are important as a source of law and the inward citation to the cited judgment that informs us of the relative importance of different precedents as sources of law. ${ }^{12}$ The citations also allow us to treat the CJEU's case law as a network where judgments make up the network's nodes, and references between judgments its directed edges - henceforth referred to as the network. As explained more fully below, this study exploits this information using two network centrality measures-Hub Score and PageRank-and examines how they are related to three characteristics of citing and cited judgments: Actions (type of procedure), areas (subject matter), and actors (parties).

Figure 1. One Citation, Two Questions, Three Dimensions

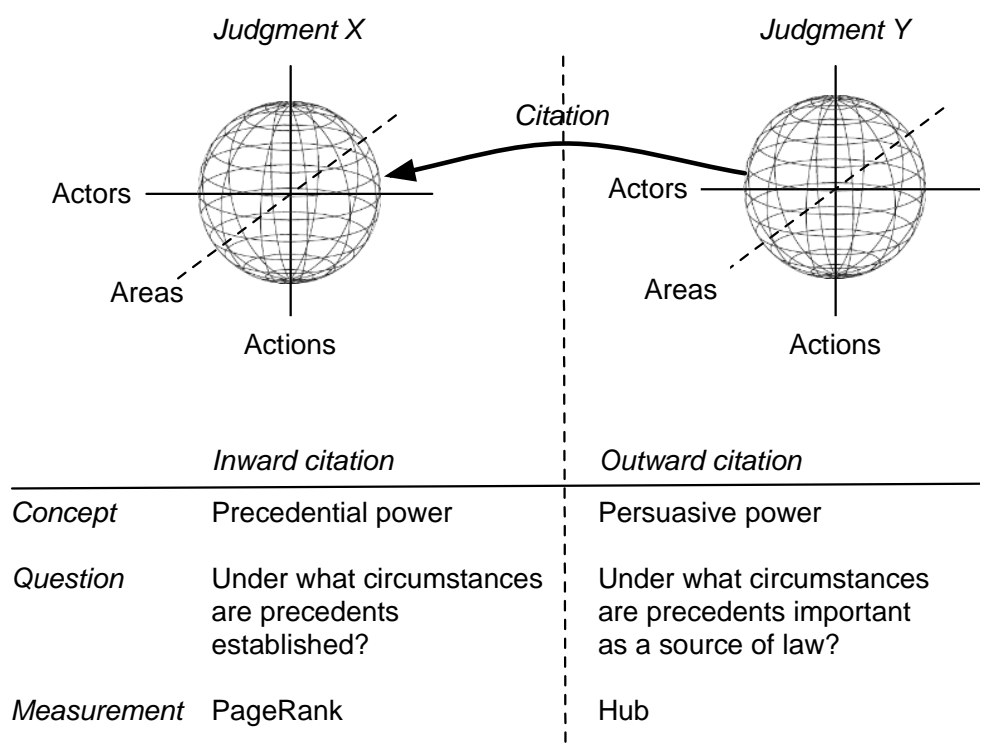

\footnotetext{
${ }^{12}$ To further complicate things, new citations change the content and structure of the law. See also infra note 36 and accompanying text.
} 


\section{Outward Citations, Persuasive Power, and Hub Score}

Starting with outward citations, we depart from the position "that 'case law' plays a major justificatory role" ${ }^{13}$ and, consequently, that a primary reason for the Court to cite precedent is to add to the legitimacy of the citing judgment. Consequently, the relative "embeddedness" of a judgment in existing case law is a reflection of its persuasive power and, by extension, the Court's strategic decisions. ${ }^{14}$

The question of the binding force of judgments is a complex one in most legal orders, ${ }^{15}$ and the EU is no exception. No court operates in a vacuum, and all courts must legitimize their decisions to external actors, ${ }^{16}$ but this is, perhaps, particularly true for the Court of Justice. The CJEU is frequently asked to settle issues of far-reaching political repercussions, ${ }^{17}$ and thus, it must carefully consider how the institutions of the European Union and the governments of the Member States will receive its decisions. The CJEU must also legitimize its judgments to the national courts. This is particularly obvious in cases brought as preliminary references, where it is ultimately up to the referring national court to settle the individual dispute. ${ }^{18}$ Yet, the need to convince national courts goes beyond this. As explained by Davies, "most EU law is applied by national courts," and "[t]he direct influence of the Court within national legal systems largely depends on the extent to which it influences these national judgments." ${ }^{19}$ Without discounting the importance of other

\footnotetext{
${ }^{13}$ Barceló, supra note 3.

${ }^{14}$ Cf. Yonathan Lupu \& James H. Fowler, Strategic Citations to Precedent on the U.S. Supreme Court, 42 J. LEGAL STUD. 151 (2013). Obviously, persuasive power in this sense differs quite distinctly from the persuasive force of judgment in a normative sense more commonly discussed in legal scholarship. The latter often employs the concept of persuasive force in relation to the traditional view of formally binding precedent, see, for example, Richard Bronaugh, Persuasive Precedent, in PRECEDENT IN LAW 217 (Laurence Goldstein ed., 1987). As part of this discussion the persuasiveness of a single judgment depends on a number of factors, including the position of the court in the hierarchy and the soundness of the reasoning, see further Aleksander Peczenik, The Binding Force of Precedent, in INTERPRETING PRECEDENT 461 (D. Neil MacCormick et al. eds., 1997). In contrast, our concept is purely empirical, measuring the extent to which a judgment is embedded in previous case law by way of citations.

${ }^{15}$ See, e.g., Peczenik, supra note 14.

${ }^{16}$ Yonatan Lupu \& Erik Voeten, Precedent in International Courts: A Network Analysis of Case Citations by the European Court of Human Rights, 42 BRIT. J. POL. SCI. 413, 417 (2011). The extreme counter-position would be that a judgment's authority exclusively follows from the position of the rendering court.

${ }^{17}$ See Takis Tridimas, The Court of Justice and Judicial Activism, 21 EUR. L. REV. 199, 203 (1996).

${ }^{18}$ Notwithstanding the fact that the CJEU expects national courts to either follow its findings or request a preliminary reference. See Joined Cases 28/62, 29/62 \& 30/62, Da Costa en Schanke v. Nederlandse Belastingadministratie, 1963 E.C.R. 61.

${ }^{19}$ Gareth Davies, Activism Relocated. The Self-Restraint of the European Court of Justice in its National Context, 19 J. EUR. PUB. PoL'Y 76, 76 (2012).
} 
factors, such as clear, consistent, and well-based reasoning, ${ }^{20}$ we can reasonably assume that one-actual or perceived-effective way of increasing a judgment's persuasive power is to embed it in case law, citing many and/or important previous judgments. ${ }^{21}$

Following several previous studies of case law, ${ }^{22}$ we use Hub Score as a measurement of persuasive power. A judgment's Hub Score, which is one attribute assigned to each case using Kleinberg's HITS algorithm, reflects not only the number of cited judgments, but also the relative importance of the cited judgments. ${ }^{23}$ Instead of treating all cited cases equally, the HITS algorithm assigns greater emphasis when an important case is cited. ${ }^{24}$ Thus, a judgment with a high Hub Score is a judgment that cites important judgments. ${ }^{25}$

\section{Inward Citation, Precedential Power, and PageRank}

Information inferred from the inward citation is different than that from the outward citation. When the CJEU renders a judgment, it does not merely apply the law to the facts of the case before it; it also contributes to legal development. This article argues that citations made to a judgment reflect its precedential power-its relative strength as a reason for reaching a similar conclusion in subsequent cases. ${ }^{26} \mathrm{~A}$ judgment that is cited by more judgments, or by more important judgments, has more precedential power than other judgments.

\footnotetext{
${ }^{20}$ The reasoning of the CJEU has been heavily criticized as lacking in transparency. For an overview see Mattias Derlén, Multilingual Interpretation of CJEU Case Law: Rule and Reality, 39 EUR. L. REV. 295, 296-98 (2014).

${ }^{21}$ Cf. Lawrence M. Friedman et al., State Supreme Courts: A Century of Style and Citation, 33 STAN. L. REV. 773, 794 (1981); Thomas G. Hansford \& James F. Spriggs II, The Politics of Precedent 16-23 (2008); Marc Jacob, Precedent and CASE-BASEd ReAsoning IN tHe EuRopean Court Of Justice 100 (2014).

${ }^{22}$ See, e.g., James H. Fowler et al, Network Analysis and the Law: Measuring the Legal Importance of Precedents at the U.S. Supreme Court, 15 POL. ANALYSIS 324 (2007).

${ }^{23}$ Jon M. Kleinberg, Authoritative Sources in a Hyperlinked Environment, 46 J. ACM 604 (1999).

${ }^{24}$ In the HITS algorithm, "importance" is measured as Authority score and calculated on the basis of the judgments citing it. A good Authority is a node pointed to by many good Hubs and a good Hub is a node that points to many good Authorities.

${ }^{25}$ In a network of case law, authorities and hubs can be translated as influential judgments and judgments that are well founded in law. See Fowler, supra note 22, at 331. For a discussion of important hubs in the case law of the CJEU, see Mattias Derlén \& Johan Lindholm, Goodbye van Gend en Loos, Hello Bosman? Using Network Analysis to Measure the Importance of Individual CJEU Judgments, 20 EUR. L.J. 667, 685 (2014).

${ }^{26}$ William M. Landes \& Richard A. Posner, Legal Precedent: A Theoretical and Empirical Analysis, 19 J. L. \& Econ. 249, 250 (1979). It is important to remember that precedential power in this sense, viz. to what extent a judgment has actually affected subsequent judgments, differs quite distinctly from the more common, normative legal concept of precedence that, for example, provides that courts should cite and follow judgments rendered by certain institutions.
} 
This study uses a slightly modified version of the original PageRank algorithm-which serves as the basis for how Google ranks webpages - as a measurement of precedential power. Very simplified, PageRank allows a "Random Walker" to explore the structure of the network by randomly following citations and occasionally teleporting to a random link in the network. ${ }^{27}$ PageRank, which is expressed as a percentage value, represents the relative probability that the Random Walker will find itself in a certain place and represents, as applied to a case law network, a judgment's popularity. ${ }^{28}$ This article concludes that PageRank constitutes the most accurate measurement of precedential value because it distributes importance relatively, neither giving equal weight to all citations nor giving all weight to the oldest decisions. ${ }^{29}$

\section{CJEU Judgments in Three Dimensions}

It is generally accepted that the role of CJEU case law differs depending on the characteristics of a particular case. ${ }^{30}$ We have previously demonstrated that the legal importance of individual judgments differs greatly depending on how one defines "important," ${ }^{31}$ and in a forthcoming publication show that both outward and inward citations follow the same Power-Law Distribution found in legal systems that rely heavily on case law. ${ }^{32}$

\footnotetext{
${ }^{27}$ The chance of a teleport, in the algorithm expressed as the damping factor (d), affects how far back in a chain of citations the Random Walker will travel. Because of the comparatively limited size of the CJEU's case law network, we use a factor of 0.5 (compare with the original where $d=0.85$ ). We want to emphasize that while the exploration is random, the outcome is not. The Random Walker follows actual citations between judgments and given enough exploration reveals the structure of the citation network.

${ }^{28}$ See Sergey Brin \& Lawrence Page, The Anatomy of a Large-Scale Hypertextual Web Search Engine, 30 COMPUTER NETWORKS \& ISDN SYS. 107 (1998); Lawrence Page et al., The PageRank Citation Ranking: Bringing Order to the Web (1998), http://ilpubs.stanford.edu:8090/422/1/1999-66.pdf.

${ }^{29}$ An obvious alternative to PageRank is Authority Score, which is the other value, besides Hub Score, produced by the HITS algorithm, see supra chapter B.II, used for example, in James H. Fowler \& Sangick Jeon, The Authority of Supreme Court Precedent, 30 SOC. NETWORKS 16 (2008). The main advantage of PageRank over Authority as a measure of precedential value is that PageRank allows, by use of a Random Walker and modifiable through the damping factor, see supra note 27 , precedential weight to be given when appropriate to a judgment that was not cited directly but that served as the basis for a judgment that was cited. See Mattias Derlén et al., Coherence Out of Chaos: Mapping European Union Law by Running Randomly Through the Maze of CJEU Case Law, 16 EUROPARÄTTSLIG TIDSKRIFT 517, 520-24 (2013). Thus, Authority Score will tend to disadvantage foundational cases, for instance, cases on which further case law is built, without necessarily having accumulated many citations. An example of this is the well-known Case 14/83, von Colson, the foundation of the principle of indirect effect. When using PageRank, the case is one of the top ten cases, but the case has a limited Authority Score $(.00082$, as measured in 2011), placing the case at place 60. See also Derlén \& Lindholm, supra note 25, at 678. Unfortunately, there is no comparable, alternative centrality measurement for Hub Score.

${ }^{30}$ See, e.g., NigEL Foster, EU LAW 64 (2014).

${ }^{31}$ Derlén \& Lindholm, supra note 25.

${ }^{32}$ Derlén \& Lindholm, supra note 6.
} 
While it is quite clear that CJEU judgments vary in persuasive and precedential power, it is less clear to what such differences are attributed. Existing scholarship contains numerous claims about the varying importance of CJEU case law as a source of law, but few of these claims have been empirically supported or tested. ${ }^{33}$ This study examines to what extent differences in a judgment's persuasive and precedential power follow the characteristics of the citing or cited judgment respectively.

In so doing, this study considers three characteristics of each case: (i) the type of action(s) under which the case was brought, including the outcome for actions that have a binary winner-loser outcome ("actions"), (ii) what area(s) of law the case concerns ("areas"), and (iii) which actors were involved in the case ("actors"). These three characteristics are most likely to affect the persuasive and precedential power of the judgment. This assertion is supported by the aforementioned scholarship that, as more fully described below, has made claims about the impact of these characteristics on the importance of CJEU case law as a source of law.

All findings of this article are made on the basis of a subset of CJEU judgments-more specifically, a dataset comprised of all 5,578 judgments rendered by the CJEU between 1992 and 2011. While the authors of this article have access to the entire dataset of CJEU judgments-consisting of 8,891 judgments and 38,261 citations made by the CJEU between 1954 and 2011-and make use of this dataset to calculate specific values on the level of individual judgments, ${ }^{34}$ there is good reason to limit the time period examined. As further discussed in other publications, the citation practice of the CJEU has changed dramatically over the years, with a significant shift in the late 1980 s and early $1990 \mathrm{~s}^{35}$ The sample used constitutes sixty-one percent of total CJEU judgments and gives a fair and representative picture of modern CJEU case law. ${ }^{36}$

\footnotetext{
${ }^{33}$ But see JACOB, supra note 21 (conducting a limited empirical study).

${ }^{34}$ When we calculate Hub Score and PageRank for individual judgments, we take the entire dataset into account. Thus, the examination is limited to judgments rendered 1992-2011, but when we measure the PageRank and Hub Score of those judgments, we take the entire network into account. To do otherwise would produce strange results. Say, for example, that we are interested in the Hub Score of a group of recent judgments, and that they cite the seminal cases 8/74 Dassonville and 120/76 Cassis de Dijon, two of the most significant authorities in the network. See Derlén \& Lindholm, supra note 25, at 685-86. If judgments before 1992 were not considered when calculating Hub Score, we would erroneously conclude that the judgments discussed have very low Hub Score, despite being firmly embedded in previous case law.

${ }^{35}$ See Derlén \& Lindholm, supra note 25, at 675; Derlén \& Lindholm, supra note 6 (providing greater detail on the matter). By 1989, average out-degree per case had reached 2.25, exceeding 2 for the first time and only ever increasing thereafter. Even more importantly, the yearly percentage of cases citing at least one previous case reached eighty percent by 1989 , never to dip below that threshold again, instead approaching a hundred percent in recent years.

${ }^{36}$ Naturally, this is a snapshot of CJEU case law as it stood in 2011. One challenge when exploring case law using network analysis is that the network constantly changes. This is particularly true when using Hub Score,
} 
Based on the dataset, this study calculates the mean Hub Score and PageRank for groups of cases that share a value for one of the aforementioned characteristics: Actions, areas, or actors. $^{37}$ This provides a relative measurement for how the precedential and persuasive power of a judgment varies depending on the characteristics of the underlying case.

One methodological challenge is that in our network, like many other large networks such as the World Wide Web, link distribution does not follow a Normal Distribution, but a Power-Law Distribution. In a Normal Distribution-also known as a bell curve-most values cluster around the middle of the range, the mean, and gradually decrease towards the lower and upper end of the spectrum. By comparison, in a Power-Law Distribution-also known as a long tail-links are increasingly accumulated in a few nodes following a "richget-richer" phenomenon. ${ }^{38}$ Mean scores are of limited importance in a Power-Law Distribution. For example, the mean population of all cities in a country is a poor representation of the population of an average city because the great majority of the urban population is concentrated in a few large cities. ${ }^{39}$ This is less of a problem when mean score, as here, is only used relatively to compare different sets. ${ }^{40}$

A more serious issue with the Power-Law Distribution is that the inclusion or exclusion of a single node can significantly impact the mean score. To resolve this issue, this study employs bootstrap resampling to determine the statistical significance of the mean scores found. This means, more specifically, that for each group of cases considered, 10,000 random samples are created of the same size and with the same age distribution as the group from the larger dataset. The study considers the examined group's mean score statistically significantly different if it falls outside ninety-five percent of the samples'

PageRank, and other feedback centrality measures as every new link added affects the centrality of all nodes in the network. This is not merely a methodological problem. From a legal perspective, a court citing, interpreting, and developing a previous decision represents a legal shift; the law is not the same as it was just moments before. We seek to explore this issue and how to overcome it in future studies.

${ }^{37}$ For example, that the case was brought as a preliminary reference (actions), by the Commission (actors), or concerned the free movement of goods (area).

${ }^{38}$ See, e.g., Albert-László Barabási \& Réka Albert, Emergence of Scaling in Random Networks, 286 SCI. 509 (1999). Consequently, the traditional measurement of standard deviation becomes unhelpful, and is not employed in this study. The standard deviation for Hub Score as well as PageRank is higher than the mean (.000172 as compared to .000131 and .000167 as compared to .000103 , respectively) due to the Power-Law Distribution. For more on the distribution of links in the network, see Derlén \& Lindholm, supra note 6 . That citations follow a Power-Law Distribution is not as such problematic or grounds for criticism; they naturally arise in, for example, business networks, social networks, transportation networks, academic citation, and the World Wide Web. See, e.g., Barabási \& Albert, supra note 38.

${ }^{39}$ Aaron Clauset et al., Power-Law Distribution in Empirical Data, 51 SIAM REV. 661, 662 (2009).

${ }^{40}$ To use the same example, it can be fruitful to compare average city population in Sweden and in the United States. 
average means. Finally, this study analyzes the extent to which its findings coincide with previously made claims about the role of CJEU case law as a source of law.

\title{
C. Actions
}

The Treaty on the Functioning of the European Union provides an exhaustive list of actions that may be brought before the CJEU, who may bring such actions, and who may be the subject of such actions. An obvious distinction exists between, on one hand, direct actions-where the Court has jurisdiction to settle disputes brought against EU institutions, the Member States, and individuals with finality-and, on the other hand, preliminary references in which the Court answers questions posed by national courts and tribunals concerning the interpretation of the Treaties and the validity and interpretation of secondary acts. ${ }^{41}$

The dominant view in existing literature is that there are important differences between the aforementioned procedures, mainly in the sense that the Court's development of EU law has primarily been achieved through preliminary reference. ${ }^{42}$ For example, Craig describes preliminary references as both the basis and the "procedural vehicle" for the development of some of EU law's most fundamental concepts. ${ }^{43}$ According to Jacob, most CJEU "landmark cases" are preliminary references. ${ }^{44}$ Similarly, Schepel and Blankenburg conclude that the Court "has refrained from turning [judicial review] into a vehicle of general constitutional review [and] has instead opted for the preliminary reference procedure to chant the mantras of Community law." ${ }^{45}$

\footnotetext{
${ }^{41}$ TFEU art. 267.

${ }^{42}$ See, e.g., Alter, supra note 2, at 126-29, 122
}

\begin{abstract}
A significant part of the 'transformation' of the EU legal system has been explained by legal scholars who have shown how the Court turned the 'preliminary ruling system' of the EU from a mechanism to allow individuals to challenge EC law in national courts into a mechanism to allow individuals to challenge national law in national court.
\end{abstract}

\footnotetext{
See also Alec Stone Sweet \& Thomas L. Brunell, Constructing a Supranational Constitution: Dispute Resolution and Governance in the European Community, 92 AM. Pol. SCI. REV. 63, 65-66 (1998).

${ }^{43}$ Paul Craig, The Jurisdiction of the Community Courts Reconsidered, in THE EUROPEAN COURT OF JUSTICE 177, 182-83 (Gráinne de Búrca \& J.H.H. Weiler eds., 2001).

${ }^{44}$ JACOB, supra note 21 , at 19 . Regarding what constitutes an important decision, see Derlén \& Lindholm, supra note 25 .

${ }^{45}$ Harm Schepel \& Erhard Blankenburg, Mobilizing the European Court of Justice, in THE EUROPEAN COURT OF JUSTICE supra note 43 , at 9, 41-42.
} 
This article concludes that the role of case law as a source of law varies significantly between types of actions, and that precedential and persuasive powers follow largely the same pattern. ${ }^{46}$ In successful infringement proceedings, which make up twenty-two percent of all CJEU judgments and fifty-one percent of all direct actions, few important precedents can be found, and case law has limited importance as a source of law, compared to other types of actions. ${ }^{47}$ Instead, it is in preliminary references, which make up fifty-eight percent of all CJEU judgments, that the Court uses case law as a source of law and that important precedents can be found.

These findings are consistent with and confirm the claims made by scholars regarding the particularly strong role of case law as a source of law in preliminary references. Among the CJEU's most important judgments during the period studied, ${ }^{48}$ two out of three, including the top four, are preliminary references. ${ }^{49}$ While this list includes direct actions, and even successful infringement proceedings, a closer examination reveals that those decisions are largely cited on procedural points and as a matter of routine. ${ }^{50}$

The deduction that case law is a less important source of law in direct actions is, to some extent, a corollary of the conclusion that preliminary references stand as a particularly important source of law. Yet, there is a noticeable discrepancy between successful infringement proceedings and other direct actions that presents a more nuanced view of the role of CJEU case law and the Court itself. While the Court inhabits an important position, establishing precedent at the apex of Europe's judiciary, our data suggest that about a quarter of its workload consists of-more or less as a matter of routine-finding in favor of the Commission and against a Member State in infringement proceedings that are neither legally complex nor particularly important for the development of EU law.

\footnotetext{
${ }^{46}$ See infra Figures $2 \& 3$.

${ }^{47}$ Of course, this does not mean that no such cases have high precedential or persuasive power. See, e.g., Case C365/97, Comm'n v. Italy, 1999 E.C.R. I-7773; Case C-103/00, Comm'n v. Greece, 2002 E.C.R. I-1147; Case C$168 / 03$, Comm'n v. Spain, 2004 E.C.R. I-8227. However, most such cases are primarily cited in other successful infringement proceedings of limited precedential importance (most of which are not published in full text) and on points of procedure, for example, what constitutes the relevant time for assessing a failure to fulfill obligations and the placement of the burden of proof in an infringement proceeding.

${ }^{48}$ Measured as the top ten percent by PageRank.

${ }^{49}$ Case C-415/93, URBSFA v. Bosman, 1995 E.C.R. I-4921; Case C-379/98, PreussenElektra AG v. Schhleswag AG, 2001 E.C.R. I-2099; Case C-279/93, Finanzamt Köln-Altstadt v. Schumacker, 1995 E.C.R. I-225; Case C-55/94, Gebhard v. Consiglio dell'Ordine degli Avvocati e Procuratori di Milano, 1995 E.C.R. I-4165.

${ }^{50}$ See, e.g., the Court's often-cited judgments in Greece, Case C-103/00; Spain, Case C-168/03; Case C-23/05, Comm'n v. Luxembourg, 2009 E.C.R. I-124, which the Court routinely cites in infringement proceedings (many of which are summary publications) on the point that it will not consider any changes made subsequent to the period laid down in the Commission's reasoned opinion.
} 
Of particular interest in this regard are unfounded direct actions. Only about eighteen percent of all direct actions are unsuccessful, but on average, those judgments have significantly higher persuasive and precedential power than successful direct actions, and even preliminary references. While not immediately obvious, this finding makes sense. The Commission wins in more than four out of five infringement proceedings, ${ }^{51}$ and in most cases it is quite clear that the Member States have failed to meet their obligations, such as failing to promptly implement a directive. The most likely explanation for this finding is that the majority of infringement proceedings are rather uncomplicated, but unfounded cases are complex proceedings with outcomes requiring additional justification. ${ }^{52}$

${ }^{51}$ Individual parties' success rate in direct actions is part of the dataset, but not presented in full in this article.

${ }^{52}$ Another possible and combinable explanation for this finding is that the Court is more concerned with its internal standing vis-à-vis the other EU institutions and thus more careful to legitimize its findings when it goes against the Commission than against a Member State. However, our findings regarding party constellations in direct actions suggest that this is not the case. See infra Chapter E. 
Figure 2. Persuasive Power by Procedure (1992-2011)

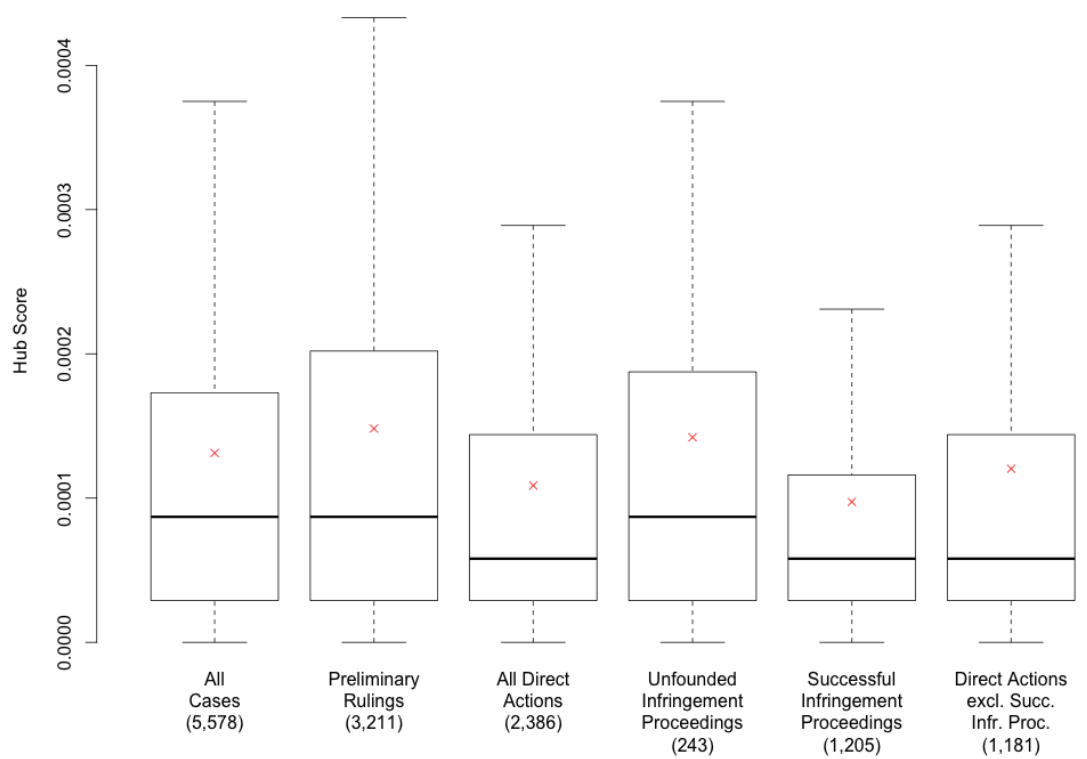

Figure 3. Precedential Power by Procedure (1992-2011)
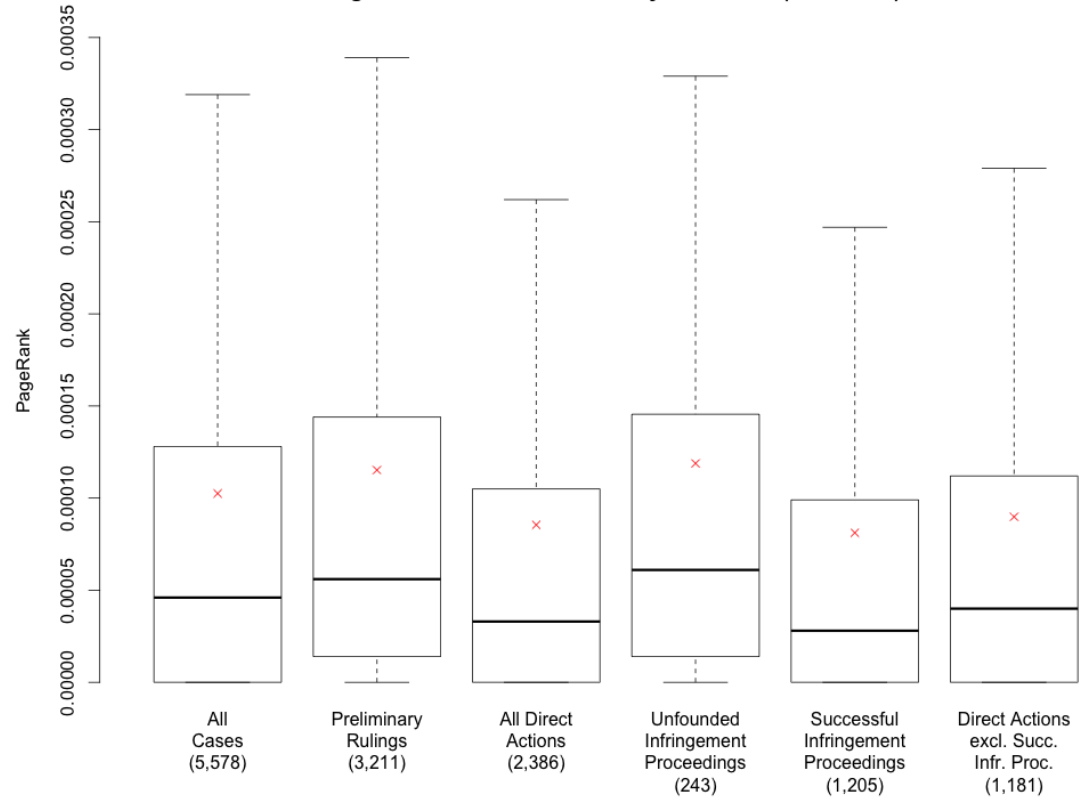


\section{Areas}

The Court of Justice's case law concerns varying areas of law. The fact that EU law "cannot be divided into the traditional branches of law found in a national legal system" ${ }^{25}$ does not mean that it is impossible or without merit to consider the role of case law in different areas of law, only that "areas of law" means something different. Indeed, the prevailing albeit vague-opinion among scholars appears to be that the role of case law as a source of law varies between different areas of law. For example, Foster argues-regarding precedential power-that "leading cases in Community law, such as Van Gend en Loos and Costa v. ENEL, have acquired a higher and more authoritative status than other casesdealing, for example, with an interpretation of one of the common customs tariff classifications or some other mundane item of EU secondary legislation." ${ }^{54}$ Another example is Davies, who explains that the criticism of judicial activism has primarily concerned four areas of EU law "of great social and legal importance," where "the central legal concepts are imprecise ones": free movement, non-discrimination law, the rules pertaining to the interpretation of directives, and the law on damages for breach of EU law. ${ }^{55}$ The prevailing view appears to be that CJEU case law is of particular importance in areas of law that are (i) important for achieving the internal market, (ii) politically sensitive to the Member States, and (iii) predominantly governed by Treaty provisions, rather than legislative acts. ${ }^{56}$ This conforms with the view of the role of case law generally. Lupu and Voeten have demonstrated that the European Court of Human Rights (ECtHR) will use past case law to a greater extent to justify its judgments when it concerns politically sensitive issues. ${ }^{57}$ Similarly, Landes and Posner argue that case law is an important source "of the specific rules of law" in legal systems where legislative bodies only provide "general norms of conduct." ${ }^{58}$

For the purpose of exploring the validity of these claims, this article uses the subject matters assigned by the Court. The Court designates between one and eleven-on average, between two and three-subject matters to each case. ${ }^{59}$ It should be noted that these designations are somewhat rough and primarily include policy areas, thereby

\footnotetext{
${ }^{53}$ Barceló, supra note 3, at 419.

${ }^{54}$ FOSTER, supra note 30 , at $76-77$.

${ }^{55}$ Davies, supra note 19 , at $79-80$.

${ }^{56} \mathrm{Cf}$. JACOB, supra note 21 , at 16-18 (arguing that in the absence of legislation and codification, "[ $t$ ]he task of putting flesh on the bones" that is the Treaties fall to the CJEU).

${ }^{57}$ Lupu \& Voeten, supra note 16.

${ }^{58}$ Landes \& Posner, supra note 26, at 249.

${ }^{59}$ The average number of subject matters has remained more or less constant since 1971.
} 
excluding a large number of issues - for example, constitutional and procedural issuesfrom being studied individually. ${ }^{60} \mathrm{~A}$ total of 136 unique subject matters occur in the data set. Many of these subject matters are, however, wholly or almost wholly ( $\geq 97 \%)$ included in another subject matter, so they are therefore excluded from separate consideration. ${ }^{61}$ Also, there are many subject matters that only occur in a very limited number of judgments and from which it is difficult to draw reliable conclusions. Consequently, this study chooses to only focus on the larger ones. ${ }^{62}$ Finally, because of their expected importance, this study analyzes the subject matters that make up competition law and fundamental freedoms both separately and collectively. As previously concluded, there are significant differences between types of actions with regard to the role of case law as a source of law. ${ }^{63}$ For this reason, the examination includes separate consideration of preliminary references (PR) and direct actions (DA). ${ }^{64}$ Several conclusions can be drawn from the data.

First, the data empirically supports the claim that the importance of CJEU case law as a source of law varies significantly between different subject matters. For example, the persuasive power of a judgment in a preliminary reference case concerning Dominant Position is, on average, three times greater than in one concerning Agriculture. While this is hardly surprising, it is valuable to establish empirically that there are indeed significant discrepancies between different areas of law, fundamentally so that we do not expect case law to be used as a source of law in the same way, and to the same extent, regardless of area of law.

Second, there are some clear differences between preliminary references and direct actions. Consistent with the previous findings regarding actions, the greatest precedential and persuasive power of case law can be found among cases brought as preliminary rulings. Both the overall mean scores and the statistically significant individual scores for preliminary references are distinctly higher than those for direct actions. The fact that the average scores for direct actions are generally lower can be explained by the same phenomenon observed above regarding the relevance of actions: Many of the cases handled by the CJEU are relatively simple infringement proceedings where the Court finds

\footnotetext{
${ }^{60}$ However, as explained further below, many of those cases fall under the subject matter Principles, objectives and tasks of the Treaties.

${ }^{61}$ For example, thirty-four subject matters always occur together with the subject matter Agriculture, including Beef \& Veal, Cereals, Dry Fodder, Flax \& Hemp, Milk Product, Sugar, and Wine. We find no plausible reason why there would be a legal difference between these categories of agricultural products.

${ }^{62}$ The lowest being Safety at Work and Elsewhere which is only a subject matter in two judgments. We have excluded subject matters raised in less than fifty cases $(n<50)$, as they constitute too small a sample.

${ }^{63}$ See supra Section C.

${ }^{64}$ See infra Table 1.
} 
that a Member State has violated Union law without needing to cite previous case law in support of this conclusion. ${ }^{65}$ Also, it is worth noting that there are many more statistically significant mean scores under preliminary references than under direct actions. This means that the impact of subject matter on the persuasive and precedential power of judgments is greater in preliminary references than in direct actions. For direct actions, only the mean scores for competition law and fundamental freedoms matters are statistically significant, and even then not as consistently as for preliminary references.

Third, consistent with existing scholarship, case law is most important as a source of law in preliminary references concerning the internal market: for instance, competition law and fundamental freedoms. Cases concerning those subject matters, and almost exclusively those cases, have statistically above-average mean values for Hub Score and PageRank. Similarly, when they are grouped together in All Competition Law and All Fundamental Freedoms, it is clear that judgments concerning these subject matters have high precedential and persuasive power. With regard to direct actions, the same is true for cases concerning All Competition Law and State Aids, whereas Free Movement of Capital and Free Movement of Services have statistically significant above-average Hub Scores.

Fourth, important differences exist between cases concerning the internal market. The five types of cases with the highest scores are-with only some variation between precedential and persuasive power-cases concerning Dominant Position (PR), State Aids (DA), Free Movement of Capital (PR), Dominant Position (DA), and State Aids (PR). The fact that case law is a more important source of law in the field of competition law than in the field of fundamental freedoms is an interesting observation considering existing legal theory. This difference is particularly surprising with regards to preliminary references. It can be noted though that All Fundamental Freedoms (PR) does edge out All Competition Law (DA). It is somewhat surprising that cases concerning competition law quite consistently have higher precedential and persuasive value than cases concerning fundamental freedom because the Court's case law on fundamental freedoms in general, and free movement of goods in particular, is often used as the primary example of how the CJEU develops EU law through case law.

It is also surprising at first glance that case law is of central importance in cases concerning Free Movement of Capital. While the free movement of capital was once less prominent than the other fundamental freedoms, it has gradually increased in importance since the beginning of the 1990s, largely through CJEU case law. As observed by Flynn, "The volume of case law relating to the free movement of capital has exploded over the past five years [and] the Court's case law has brought the capital rules in five years to the positions held

\footnotetext{
${ }^{65}$ See supra Section C.
} 
by the other freedoms after almost thirty years." ${ }^{66}$ It is thus natural that it would be a prominent area of case law during the period examined here. Central cases concerning free movement of capital include Manninen ${ }^{67}$ and Verkooijen. ${ }^{68}$ According to the collected data, these are the twentieth and twenty-third most important CJEU decisions overallranked by PageRank-between 1992 and 2011.

Fifth, excluding competition law and fundamental freedoms, there is primarily one subject matter where case law is noticeably important: Cases brought as preliminary references concerning principles, objectives, and tasks of the Treaties. In this group, we find many of the Court's central judgments concerning legal principles and constitutional matters, including such famous cases as Brasserie du Pecheur, ${ }^{69}$ Inter-Environnement Wallonie, ${ }^{70}$ Martínez Sala, ${ }^{71}$ Mangold, ${ }^{72}$ and Schmidberger. ${ }^{73}$ Thus, it should come as no great surprise that this is an area where case law plays an important role as a source of law, with high Hub Score and PageRank values. The same is, however, not equally true for cases concerning this subject matter when they are brought as direct actions.

Finally, this approach also allows us to identify subject matters where case law is of less importance as a source of law. This study's findings reveal that judgments in cases concerning agriculture and the approximation of laws have comparatively low precedential and persuasive power, regardless of whether they are brought as preliminary references or direct actions. One likely explanation for this is that such cases concern the interpretation, implementation, and application of specific legislative acts, and the relevance of other cases is relatively limited. This explanation is supported by an examination of the use of legislative acts as a source of law. For example, whereas CJEU judgments in preliminary reference cases contain on average 2.03 references to Directives and Regulations, judgments in preliminary reference cases concerning agriculture refer to 2.97 such legislative acts on average. ${ }^{74}$

\footnotetext{
${ }^{66}$ Leo Flynn, Coming of Age: The Free Movement of Capital Case Law 1993-2002, 39 Common Mkt. L. Rev. 773, 804 (2002).

${ }^{67}$ Case C-319/02, Manninen, 2004 E.C.R. I-7477.

${ }^{68}$ Case C-35/98, Staatssecretaris van Financiën v. B.G.M. Verkooijen, 2000 E.C.R. I-4071.

${ }^{69}$ Joined Cases C-46/93 \& 48/93, Brasserie du Pecheur SA v. Germany, The Queen v. Sec'y of State for Transport, 1996 E.C.R. I-1029.

${ }^{70}$ Case C-129/96, Inter-Environnement Wallonie ASBL v. Région Wallonne, 1997 E.C.R. I-7411.

${ }^{71}$ Case C-85/96, Martínez Sala v. Freistaat Bayern, 1998 E.C.R. I-2691.

${ }^{72}$ Case C-144/04, Mangold v. Helm, 2005 E.C.R. I-9981.

${ }^{73}$ Case C-112/00, Schmidberger, Internationale Transporte und Planzüge v. Austria, 2003 E.C.R. I-5659.

${ }^{74}$ The second to highest average is Customs Union with 2.25 references.
} 
Table 1. Mean Scores by Subject Matter (1992-2011)

\begin{tabular}{|c|c|c|c|c|c|c|}
\hline \multirow[b]{2}{*}{ Type } & \multicolumn{3}{|c|}{ Preliminary References } & \multicolumn{2}{|c|}{$\underline{\text { Direct Actions }}$} & \multirow[b]{2}{*}{ PageRank } \\
\hline & $N$ & $\begin{array}{l}\text { Hub } \\
\text { Score }\end{array}$ & PageRank & $N$ & $\begin{array}{l}\text { Hub } \\
\text { Score }\end{array}$ & \\
\hline All Cases & 3,211 & .000148 & .000115 & 2,386 & .000108 & .000085 \\
\hline $\begin{array}{l}\text { All Competition } \\
\text { Law }\end{array}$ & 127 & $.000272 *$ & $.000217^{*}$ & 272 & $.000178^{*}$ & $.000139 *$ \\
\hline $\begin{array}{l}\text { Concerted } \\
\text { Practices }\end{array}$ & 13 & .000216 & .000177 & 67 & $.000201 *$ & $.000156^{*}$ \\
\hline $\begin{array}{l}\text { Dominant } \\
\text { Position }\end{array}$ & 49 & $.000312 *$ & .000263 & 34 & .000139 & .000114 \\
\hline State aids & 71 & $.000262 *$ & $.000203 *$ & 176 & $.000175^{*}$ & $.000135 *$ \\
\hline $\begin{array}{l}\text { All Fundamental } \\
\text { Freedoms }\end{array}$ & 830 & $.000224^{*}$ & $.000182 *$ & 478 & $.000116^{*}$ & $.000090^{*}$ \\
\hline $\begin{array}{l}\text { Free Movement } \\
\text { of capital }\end{array}$ & 83 & $.000289 *$ & $.000239 *$ & 37 & $.000157^{*}$ & $.000113^{*}$ \\
\hline $\begin{array}{l}\text { Free Movement } \\
\text { of services }\end{array}$ & 334 & .000203 & .000160 & 258 & .000112 & .000088 \\
\hline $\begin{array}{l}\text { Free Movement } \\
\text { of Workers }\end{array}$ & 216 & $.000229 *$ & .000180 & 106 & .000127 & .000106 \\
\hline $\begin{array}{l}\text { Quantitative } \\
\text { Restrictions }\end{array}$ & 188 & .000231 & .000189 & 78 & .000136 & .000112 \\
\hline $\begin{array}{l}\text { Right of } \\
\text { Establishment }\end{array}$ & 346 & .000200 & $.000165^{*}$ & 302 & .000108 & .000082 \\
\hline Agriculture & 427 & $.000101^{*}$ & $.000078^{*}$ & 296 & .000111 & .000087 \\
\hline $\begin{array}{l}\text { Approximation of } \\
\text { Laws }\end{array}$ & 553 & $.000133^{*}$ & $.000107^{*}$ & 450 & .000096 & .000084 \\
\hline $\begin{array}{l}\text { Brussels } \\
\text { Convention }\end{array}$ & 76 & $.000137^{*}$ & $.000089 *$ & --- & --- & --- \\
\hline $\begin{array}{l}\text { Consumer } \\
\text { Protection }\end{array}$ & 113 & $.000114^{*}$ & $.000084^{*}$ & 40 & .000091 & .000063 \\
\hline Customs Union & 293 & $.000113^{*}$ & $.000086^{*}$ & 24 & .000108 & .000071 \\
\hline Environment & 123 & $.000135^{*}$ & .000117 & 414 & .000092 & .000082 \\
\hline External Relations & 149 & $.000141 *$ & $.000104^{*}$ & 114 & .000129 & .000098 \\
\hline Financial Provisions & 19 & .000117 & .000087 & 45 & .000123 & .000088 \\
\hline $\begin{array}{l}\text { Industrial and } \\
\text { Commercial } \\
\text { Property }\end{array}$ & 164 & $.000128^{*}$ & .000108 & 84 & .000114 & .000087 \\
\hline
\end{tabular}




\begin{tabular}{|c|c|c|c|c|c|c|}
\hline $\begin{array}{l}\text { Principles, } \\
\text { Objectives and } \\
\text { Tasks of the } \\
\text { Treaties }\end{array}$ & 127 & $.000229 *$ & $.000181^{*}$ & 47 & .000131 & .000098 \\
\hline $\begin{array}{l}\text { Provisions } \\
\text { Governing the } \\
\text { Institutions }\end{array}$ & 34 & .000221 & .000169 & 74 & .000091 & .000062 \\
\hline Social Provisions & 301 & $.000141 *$ & $.000103 *$ & 81 & .000124 & .000115 \\
\hline $\begin{array}{l}\text { Social Security for } \\
\text { Migrant Workers }\end{array}$ & 208 & $.000133 *$ & $.000096^{*}$ & 19 & .000091 & .000071 \\
\hline Taxation & 496 & .000168 & .000135 & 122 & .000119 & .000091 \\
\hline Transport & 86 & .000137 & .000111 & 100 & .000089 & .000071 \\
\hline
\end{tabular}

With regard to direct actions, a low Hub Score can also, as discussed above, be explained by the relatively high number of successful infringement proceedings: eighty-nine percent and ninety-four percent of all direct actions concerning the approximation of laws and environment, respectively, are successful infringement proceedings.

\section{E. Actors}

As explained above, it is reasonable to assume that the role of CJEU case law as a source of law will differ depending on the actors involved. In other words, the Court's effort to embed one of its judgments in existing case law will differ depending on which, and how many, actors are involved in the particular case. For example, the Court can be expected to rely more heavily on case law in cases involving common law jurisdictions compared to civil law jurisdictions, considering the importance of case law in the common law traditions. ${ }^{75}$

The Court reasonably also has a greater need to legitimize its judgments in highly sensitive or controversial cases, and this will cause those judgments to be more heavily embedded in existing case law. This prediction is partially supported by the previously discussed findings that subject matter generally, and certain potentially sensitive subject matters in particular, has an impact on the use of case law. However, the prediction can also be tested by focusing on the actors involved in a case. Not all cases settled by the Court are politically charged. While many are outright uncontroversial, in some cases the Court acts as a "referee," settling disputes between the Member States and the EU institutions. Jacob argues that the multiplicity and diversity of legal and political influences within the EU legal order adds to the importance of CJEU precedent in the EU legal order. ${ }^{76}$ Based on these

\footnotetext{
${ }^{75}$ Cf. Lupu \& Voeten, supra note 16 , at 421.

${ }^{76}$ JACOB, supra note 21, at 18-19.
} 
considerations, a positive correlation is expected between the number of actors involved in a case and the extent to which the judgment is embedded in case law.

One actor that should not be forgotten is the Court itself. While the Court is a single institution, its composition differs between cases. Whereas smaller chambers decide roughly four out of five cases, the remaining one-fifth are adjudicated by the Full Court (before 2004) or the Grand Chamber (after 2004). ${ }^{77}$ This study finds that cases singled out for such preferential treatment distinguish themselves when it comes to the use of case law as a source of law. Judgments in such cases make up half of the top ten percent strongest precedents, ${ }^{78}$ with a mean PageRank that is almost double the average. ${ }^{79}$ Similarly, these judgments are almost twice as heavily embedded in existing case law as the average judgment. ${ }^{80}$ Thus, it is fair to say that much of the development of CJEU case law, both in terms of precedential and persuasive power, is concentrated in cases settled by the Full Court and the Grand Chamber. It is important to note, however, that not all such cases turn out to be important, and there are, as explained elsewhere in this paper, other factors that even more strongly predict precedential and persuasive power.

Regarding other actors, it should first be noted that the actors involved in a case differ greatly between direct actions and preliminary references. Roughly half of all direct actions are successful infringement proceedings brought by the Commission against a Member State, and case law is of relatively limited importance in those cases. ${ }^{81}$ Thus, if one considers all direct actions, it appears that when the Commission is the applicant, or a Member State is the defendant, both the precedential and persuasive power of the judgment is reduced. While this note is true in a certain sense, it adds nothing here and clouds the possible importance of the actors in other types of direct actions. Therefore, this part excludes successful infringement proceedings from consideration. ${ }^{82}$

\footnotetext{
${ }^{77}$ Until the European Union's enlargement in 2004, the Full Court would decide certain-presumably more important-cases collectively, whereas other-presumably less important-cases would be heard by smaller chambers. During the time period examined in this study, the Full Court consisted of twelve to fifteen members. Since the enlargement, the Court rarely sits as a full court, instead relinquishing its role to the Grand Chamber, a composition comprising of a minimum of thirteen judges.

${ }^{78}$ Ranked by PageRank, making them overrepresented by 2.5 times.

${ }^{79}$ They have a mean PageRank of 000195.

${ }^{80}$ They have a mean Hub Score of .000226 . Judgments made by the Grand Chamber (i.e. after 2004) cite on average 10.59 previous judgments. That can be compared to an average of 6.10 citations for all judgments between 1992 and 2011.

${ }^{81}$ See supra Section C.

${ }^{82}$ See infra Table 2. We have only actions involving the larger institutions in the table, excluding, for example, the Community Plant Variety Office and European Maritime Safety Agency.
} 
Unfortunately, there are only 1,181 direct actions that are not successful infringement proceedings during the time period considered. When divided by the actors involved, there are too few observations to reliably draw general conclusions. The party constellations whose mean scores meet the criteria for statistical significance ${ }^{83}$ contain only a handful of cases, general conclusions should not be drawn from such a limited sample.

It is, however, interesting to note the relative difference in mean scores between constellations. Cases involving Member States, either as applicants or defendants, generally have greater precedential and persuasive power than intra-institutional disputes. This is consistent with the hypothesis that the importance of the Court is greater when it is acting as a "referee." Even though unsuccessful actions brought by the Commission against a Member State ${ }^{84}$ have relatively high persuasive and precedential power, they are not as strong as actions brought by Member States. Amongst the different actions brought by

Table 2. Mean Scores by Parties in Direct Actions Excl. Successful Infringement Proceedings (1992-2011)

\begin{tabular}{|c|c|c|c|c|c|c|}
\hline Applicant & $\frac{\text { Defendant }}{\text { Person }}$ & $\begin{array}{l}\text { Com- } \\
\text { mission }\end{array}$ & Council & $\begin{array}{l}\text { European } \\
\text { Parliament }\end{array}$ & Official & $\begin{array}{l}\text { Member } \\
\text { State }\end{array}$ \\
\hline \multirow[t]{3}{*}{ Person } & .000091 & .000144 & .000109 & .000062 & --- & .000158 \\
\hline & .000069 & .000112 & .000079 & .000030 & & $.000109 *$ \\
\hline & (30) & $(284)$ & $(58)$ & (8) & & (12) \\
\hline \multirow[t]{3}{*}{ Commission } & .000094 & --- & .000125 & .000069 & .000167 & .000099 \\
\hline & .000066 & & .000093 & $.000049 *$ & .000141 & .000072 \\
\hline & $(73)$ & & (30) & (5) & $(14)$ & $(280)$ \\
\hline \multirow[t]{3}{*}{ Council } & .000096 & --- & --- & .000044 & .000058 & --- \\
\hline & .000052 & & & .000014 & .000035 & \\
\hline & (3) & & & $(2)$ & (4) & \\
\hline European & .000116 & .000122 & .000112 & --- & .000082 & --- \\
\hline \multirow[t]{2}{*}{ Parliament } & $.000100 *$ & .000084 & .000096 & & .000043 & \\
\hline & $(2)$ & (5) & $(27)$ & & $(12)$ & \\
\hline \multirow[t]{3}{*}{ Official } & --- & .000085 & .000101 & .000063 & --- & --- \\
\hline & & .000063 & .000065 & .000027 & & \\
\hline & & $(44)$ & (4) & $(12)$ & & \\
\hline \multirow[t]{3}{*}{ All MS } & .000116 & .000136 & .000187 & .000151 & --- & .000106 \\
\hline & .000083 & .000101 & .000155 & $.000101 *$ & & .000064 \\
\hline & $(11)$ & $(211)$ & (55) & $(14)$ & & (4) \\
\hline
\end{tabular}

Note: ${ }^{*} \mathrm{p}<.05$. Hub Score in bold, PageRank italicized, $\mathrm{N}$ in parenthesis.

\footnotetext{
${ }^{83}$ See supra Section B.IV.

${ }^{84}$ Successful infringement proceedings are excluded from consideration in this part.
} 
Member States, cases brought against the Council appear to have the greatest precedential and persuasive power of all party constellations in direct actions.

Unexpectedly, it appears that case law also plays an important role in actions brought by individual persons against the Commission. This category includes the judgments in Bergaderm-frequently cited regarding the non-contractual liability of the Union and individuals' right to have their matter adjudicated within a reasonable time $-{ }^{85}$ and in Baustahlgewebe-concerning the procedural rights of the individual. ${ }^{86}$

Unlike direct actions before the CJEU, there are no formal defendants and applicants in a preliminary reference proceeding. That is not to say, however, that it is irrelevant who is involved in the case. As previously explained, this study expects the role of case law to change with the legal tradition of the referring court based on the theory that governments and courts of common law jurisdictions, Ireland and the United Kingdom in the case of the EU, are, in accordance with their domestic legal tradition, more likely to find a judgment persuasive if it is embedded in existing case law. Although citing case law may also add to the persuasiveness of a judgment in the eyes of governments and courts of civil law jurisdictions, such as France, we expect it to be less persuasive, and for the CJEU to act accordingly. If this theory holds true, we would expect judgments in preliminary references originating from common law countries to have a higher Hub Score than those originating from civil law countries.

This study uses the official language of the CJEU case, which is also the language of the referring court, ${ }^{87}$ to identify the legal tradition of the referring national court. Naturally, this is a simplification, ${ }^{88}$ but it serves as a convenient shorthand in the European legal context, enabling us to group countries like Austria and Germany together.

We find that with regard to most Member States, the Court's use of case law does not vary significantly-either in terms of persuasive or precedential power-depending on the nationality of the referring court. For example, the mean persuasive and precedential power of preliminary references originating in German speaking (civil law) countries is lower than those of any other group, but not to such a degree that it is statistically

\footnotetext{
${ }^{85}$ Case C-352/98 P, Bergaderm SA \& Goupil v. Comm'n, 2000 E.R.C. I-5291.

${ }^{86}$ Case C-185/95 P, Baustahlgewebe GmbH v. Comm'n, 1998 E.R.C. I-8417.

${ }^{87}$ Rules of Procedure of the Court of Justice, EUT (L 265) 29.09.2012, art. 37.3., at 1-42.

${ }^{88}$ Legal language is dependent on national legal traditions and culture, which is why legal concepts can vary in meaning between countries with the same national language and even within a country. See Barbara Pozzo, Multilingualism, Legal Terminology and the Problems of Harmonising European Private Law, in MULTILINGUALISM AND THE HARMONISATION OF EUROPEAN LAW 3, 6-8 (Barbara Pozzo \& Valentina Jacometti eds., 2006) (providing an introduction to this subject).
} 
significant. We do find, however, that the mean Hub Score of preliminary references originating from courts in the English-speaking countries- Great Britain and Ireland-is quite markedly, and statistically significantly, greater. The same is also true for the precedential power of preliminary references originating in these countries. ${ }^{89}$

We are hesitant to conclude, based on this finding, that the Court takes national legal tradition into account when drafting its preliminary references. While it is clear that preliminary references from Great Britain and Ireland are treated differently than other preliminary references, the data involved in this study does not establish its cause. The fact that preliminary references originating in British and Irish courts distinguish themselves in the case law of the CJEU, both with regard to the use of case law-persuasive power-and their importance as a source in subsequent cases-precedential power-may be attributable to factors other than the referring courts' legal tradition. There may be another characteristic that these nations, or the preliminary references made by their courts, have in common that separates them from other Member States. For example, if a preliminary reference originates in a common law country, it is possible that the lawyers involved are more used to arguing by reference to case law compared to cases originating in civil law countries, and this may, in turn, affect the inclusion of such references in the judgment.

Table 3. Mean Scores by Official Language in Preliminary References, EU 15 (1992-2011)

\begin{tabular}{llll}
\hline \hline & $N$ & Hub Score & PageRank \\
\hline Dutch & 472 & .000144 & .000109 \\
English & 350 & $.000184^{*}$ & $.000148^{*}$ \\
$\begin{array}{l}\text { French } \\
\text { Other Romance }\end{array}$ & 437 & .000155 & .000121 \\
Languages $^{90}$ & 503 & .000155 & .000122 \\
German & & & \\
Greek & 1,068 & .000140 & .000109 \\
Scandinavian & 72 & .000163 & .000116 \\
Note: ${ }^{*}$ p $<.05$. & 214 & .000153 & .000122 \\
& & &
\end{tabular}

In cases brought as preliminary references, "the parties, the Member States, the Commission and, where appropriate, the institution, body, office or agency which adopted the act the validity or interpretation of which is in dispute, shall be entitled to submit

\footnotetext{
${ }^{89}$ See infra Table 3.

${ }^{90}$ Italian, Portuguese, and Spanish.

${ }^{91}$ Danish, Finnish, and Swedish.
} 
statements of case or written observations to the Court." ${ }^{92}$ Those allowed make extensive use of the opportunity to provide such observations, and few preliminary references proceed without observations having been submitted. The number of observations submitted, however, differs distinctly between cases. ${ }^{93}$ Whereas the Court will usually receive only one or two observations, it will in some cases receive more than ten. Thus, the Member States' and EU institutions' decision to submit or not submit observations in a preliminary reference constitutes a quantifiable measurement of their involvement in the case.

The most active observant, by far, is the Commission. In the 3,164 preliminary references included in our data, the Commission submitted an observation in all but fifty-four cases, and the Commission was an observant in all but five cases where observations were submitted. ${ }^{94}$ Consequently, it is difficult for this study to draw any conclusions from the Commission's observations. Other EU institutions rarely submit observations. Thus, the number of observations made in a case primarily varies with the number of observations offered by Member States.

The persuasive power of a judgment appears related to the number of Member States that submitted an observation in the case. If at least one Member State submits an observation, the resulting judgment will have a slightly higher Hub Score. This tendency increases with the number of Member States that submit observations: The more observant Member States in a case, the more embedded the judgment will be in existing case law. ${ }^{95}$

While there is a clear connection between the number of observations submitted in a case and the embeddedness of the final judgment, it is more difficult to determine the cause. As stated above, the Court most likely uses citations to existing case law strategically to legitimize its judgment. Although Member States differ somewhat in their practice of submitting observations, a high number of submitted observations could indicate that the case is controversial ${ }^{96}$ and, in turn, that the Court would have a greater need to legitimize its judgment. If accepted, our findings about the embeddedness of such judgments support the underlying assumption of the CJEU acting strategically.

${ }^{92}$ Protocol (No. 3) on the Statute of the Court of Justice of the European Union, art. 23, para. 2.

${ }^{93}$ See infra Figure 4.

${ }^{94}$ As a result, data for Commission observations and any observation mirror each other.

${ }^{95}$ See infra Figure 4. Obviously, Hub Score is still only calculated on the basis of cases cited by the CJEU in the judgment. In another article, the authors of this article explore the relationship between the opinions expressed by the Member States in their observations and the embeddedness of the final judgment in previous case law. See Olof larsson, daniel Naurin, Mattias Derlén \& Johan lindholm, Speaking law to Power. The Strategic Use of PRECEDENT OF THE COURT OF JUSTICE OF THE EUROPEAN UNION (forthcoming).

${ }^{96}$ See Morten Broberg \& Niels Fenger, Preliminary References to the European Court of Justice 357-58 (2014). 
Member State involvement and embeddedness in case law could, however, be caused by a third factor. If a case involves a legal issue that is particularly complicated or concerns a large portion of society-without necessarily being politically controversial-this may cause more Member States to be involved in the case and the Court to embed the judgment in a greater amount of case law. From this perspective, involvement can be viewed as a "market" assessment of the legal or political importance of the issues to be settled by the Court in a particular case.

Similarly, the precedential power of a judgment is positively correlated to the number of observations submitted. Judgments in preliminary references where many observations were submitted are likely to have stronger precedential power than other judgments in preliminary references.

Figure 4. Observations Submitted (1992-2011)

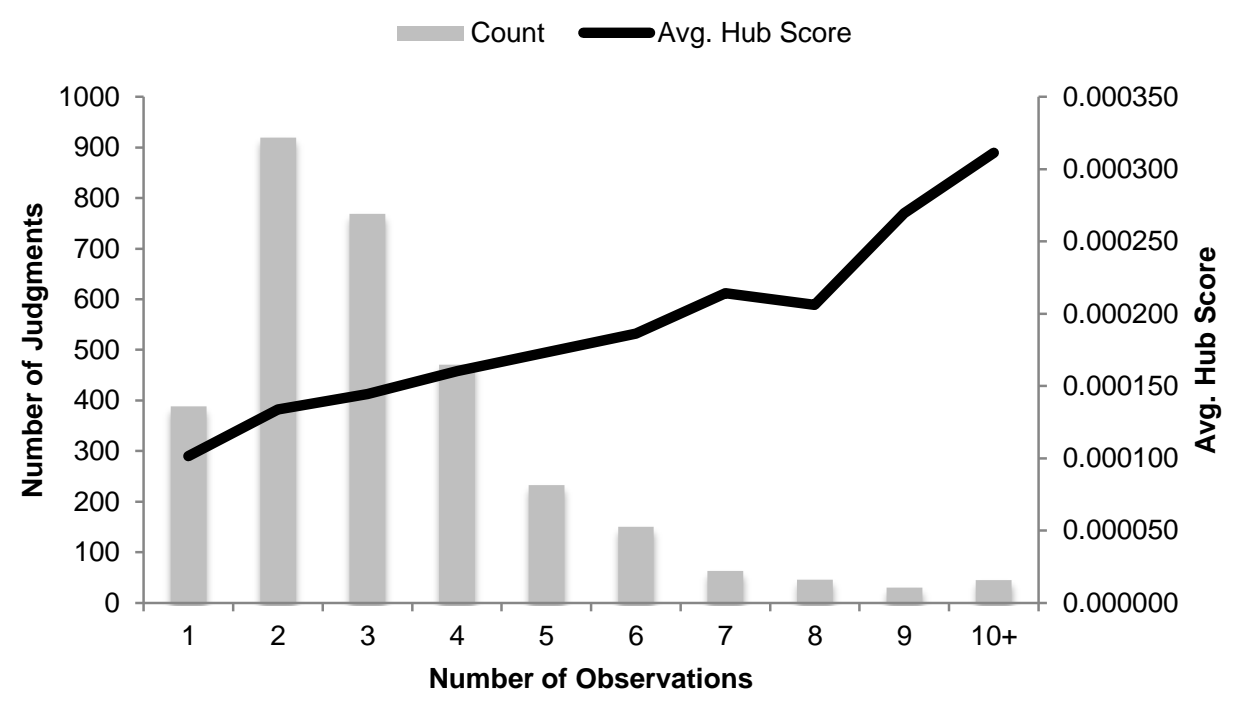

\section{F. Summary and Conclusions}

This study's findings demonstrate that there are no clear, black-and-white answers to the role of case law as a source of law. It has, however, made significant advancements in our understanding of the issue. Six conclusions may be drawn from this article's findings.

First, CJEU case law as a source of law should not be treated as a single mass. The Court fulfills many functions within the European Union, ranging from "infringement confirmer" to "constitutional referee." In all three dimensions of case law considered, these different roles are reflected in the persuasive and precedential power of its judgments. 
Second, of all the case characteristics studied here, the great majority have limited or no impact on the persuasive or precedential power of the judgment. This does not contradict the conclusion that case law generally is an important source in EU law. There are, however, only a limited number of factors studied that reliably affect a judgment's persuasive or precedential power.

Third, the Court's use of its own case law as a source of law is particularly limited in successful infringement proceedings. These cases also make up a large proportion of all cases adjudicated by the Court.

Fourth, case law's role as a source of law is especially great in preliminary references, particularly those concerning fundamental freedoms or competition law-treaty-based market rules. This confirms, consistent with previous scholarship, that case law is particularly important as a source law in those areas.

Fifth, the Court noticeably shifts its behavior depending on originating Member State, and the number of observations submitted, supporting the theory that the Court is acting strategically-knowingly or unknowingly - to maximize its persuasive power over the Member States and the national courts. This provides us with some basis for making a prognosis about which decisions will become important. Based on the factors observed above, we predict that within the next eight years, ${ }^{97}$ the CJEU will cite its recent decision $S$ $\& G$ in several important cases. ${ }^{98}$

Finally, one can observe that PageRank and Hub Score are positively correlated: Cases that have a high score for one tend to have a high score for the other, and vice versa. This is consistent with a legal system largely based on case law where law, at least in certain areas, is found in judgments based on judgments. Indeed, "Today is not only yesterday's tomorrow; it is also tomorrow's yesterday." ${ }^{\prime 9}$

\footnotetext{
${ }^{97}$ See Derlén \& Lindholm, supra note 6 (discussing the average life time of a CJEU judgment).

${ }^{98}$ Case C-457/12, S \& G v. Minister voor Immigratie, Integratie en Asiel, EU:C:2014:136. At the time of writing, the judgment has never been cited.

${ }^{99}$ See supra Section B.I.
} 